\title{
Private sector participation in solid waste collection in Addis Ababa (Ethiopia) by involving micro-enterprises
}

Waste Management \& Research

2014, Vol 32(1) 79-87

(c) The Author(s) 2013

Reprints and permissions:

sagepub.co.uk/journalsPermissions.nav DOI: $10.1177 / 0734242 \times 13513826$

wmr.sagepub.com

(S)AGE

\section{Mesfin Tilaye ${ }^{1}$ and Meine Pieter van Dijk ${ }^{2}$}

\begin{abstract}
Privatization of urban services focuses often on the involvement of foreign enterprises. This contribution deals with micro-privatization, the partial transfer of government responsibility for solid waste collection to micro-enterprises. It tries to shed light on whether the current private sector participation (PSP) of micro-enterprises in solid waste collection service is the best way to capture the expected advantages of private sector involvement. The article examines the relations of the micro-enterprises with beneficiaries and the public sector by focusing on the contract procedure, the tariff-setting process, the cost recovery mechanism and institutionalizing of market principles for micro-enterprises. The research was carried out using secondary and primary data sources. Primary data were collected through the interviewing of public sector officials at different levels, focus group discussions with community groups and micro-enterprises, and observation. A survey was conducted among 160 micro-enterprises in the city of Addis Ababa, Ethiopia, using a standard questionnaire. What are some of the factors contributing to the results of PSP in Addis Ababa, the capital of Ethiopia? Policies at higher levels of government definitely produced an overall climate conducive to micro-privatization and recognized the need to develop micro-enterprises, but it is not clear what role the micro-enterprises are to play in solid waste management. New opportunities were created by formalization and taken up by communities and micro-enterprises. Coverage and waste collected both increased. The initiation and institutionalization of the formalization process was not without problems. The public sector overstressed the autonomy of micro-enterprises. The fate of the micro-enterprises is largely determined by the reforms undertaken at local government level. The rapid changes in policies at the local level made waste-collecting micro-enterprises lose confidence and more dependent on the public sector. The study shows the continued power of the state and its agents in shaping developments in this domain.
\end{abstract}

\section{Keywords}

Private sector participation, solid waste collection, informal sector, developing countries, micro-privatization

\section{Introduction}

Many people in cities in the developing world are involved in informal activities to earn a living. These activities take place outside the legal framework, and are often driven by the struggle to survive. In many developing countries the role of informal activities has become more important (Van Dijk, 2010). Informality in solid waste management is a reality not only owing to its unavoidable nature, but also its contribution in providing service access to the marginalized, creating job opportunity to the urban poor and reducing the cost for financially-deprived municipalities (Velis et al., 2012). It also plays an important role in promoting indigenous entrepreneurship and use of indigenous resources. There is a need for a paradigm shift in the way informal sector service providers are viewed. Therefore, the Addis Ababa city government decided, in 2004, to unbundle solid waste management service into different functions and seek private sector involvement in primary solid waste collection by formalizing the micro-enterprises ( $<10$ employees and usually informal). This was part of a grand project of regulating solid waste management. In this article, municipal waste management refers to the function of 'primary collection'.

The city administration embarked on micro-privatization as the attraction of standardized privatization into this activity would for sure be unrealistic at this point in time (Harper, 2000). This is attributed to the capacity of the local government to administer the system, the nature of the waste, the awareness and capacity of beneficiaries, and, above all, the willingness of the private sector to involve in the venture. The situation called for organized and regulated primary solid waste collection in which the micro-enterprises were taken serious. We studied this institutionalization process and its outcome.

${ }^{1}$ Ethiopia Civil Service University, Addis Ababa, Ethiopia 2UNESCO-IHE, Delft, the Netherlands

\section{Corresponding author:}

Meine Pieter van Dijk, UNESCO-IHE, pobox 3015, Delft, 2601 DA, the Netherlands.

Email: m.vandijkaunesco-ihe.org 


\section{Informality in solid waste management in Addis Ababa}

There exists a vibrant informal private economy in almost all cities in the developing world, which plays a significant role in solid waste management. Integration of the informal activities in the formal sector needs to be facilitated. In the capital of Tanzania local, community-based organizations and small local businesses were facilitated to collect waste from households. Often, this kind of private sector involvement will lead to larger players entering the sector (Pan African News Agency, 2004). In Lagos State in Nigeria, for example, neighborhoods originally determined the type of private sector involved in the collection, transportation and disposal of their waste. Formal private sector enterprises operated in the high-income, low population density areas, while the informal private operators, like cart pushers, operated in low-income, high population density areas. However, with time, both the formal and informal sectors operated in both areas. Some communities preferred the use of cart pushers, who were deemed to be more reliable, as the services from formal private sector became irregular (Olugbenga, 2006).

From the point of view of solid waste modernization, informal activities should be seen as legitimate and useful private actors in the solid waste system - part of the solution, rather than part of the problem. Until 2004, solid waste collection in Addis Ababa was a sector open to all who wanted to engage in it and often collection was done by organized and unorganized groups, or by individuals, whose main source of income came from other activities, for example daily workers, shoe shine boys and street children. Collection of waste by the informal sector was carried out in accordance with the needs of households and commercial institutions without any fixed schedule. There was no concern or even awareness from the side of the users as to where and how the collected waste was disposed of. This decision was up to the waste collectors. They usually preferred to dump waste in a nearby open space or river rather than transporting it to municipal containers.

Historically, the municipality used to administer solid waste management. Taking 2002 as a base year, of the total waste generated in the city, which was about 270 tonnes day ${ }^{-1}$, only $33 \%$ was collected by the municipality door-to-door collection service, while the rest was handled either by the households themselves and the informal waste collectors, or remained uncollected in the city.

The rapid rate of uncontrolled and unplanned urbanization in the city has exacerbated the problem of solid waste management. Attempts by the Addis Ababa city government to solve solid waste management problems and to provide effective services in urban areas have been inadequate. The government's efforts have not adequately mobilized the private sector, non-governmental organizations or community initiatives (Kuma, 2004). Government structures and systems have been failing to confront the new challenges.

Understanding the complexity and the difficulty of the situation, the government and citizens in the city started to use a variety of methods of delivering solid waste management services.
Contracting out to the private sector or non-governmental organizations (NGOs), decentralization of functions to local governments and community participation are some of the modalities used. Considering the constraints on public agencies to achieve the intended objectives, the city authorities tried to resort to one form of private sector participation or another.

In 2004 the city government of Addis Ababa intervened in solid waste collection by institutionalizing micro-enterprises. This was part of a grand scheme to privatize solid waste management. Similar initiatives to allow more space for private operators were analyzed in Oduro-Kwarteng and van Dijk (2013), Cointreau and Coad (2000) and Coad (2005).

The day-to-day administration of the solid waste collection service was handled by the Kebele's (the lowest level of administration, below the sub-city) Integrated Solid Waste Management case teams. These case teams liaise closely with the microenterprises, the city authority and the community. The city authority (agency) retains the responsibility for planning, providing guidelines and setting standards. The micro-enterprises play an important role in the running of the operational function of the solid waste collection. The privatization of the service is based on the principle of public ownership and private operation. The local government remains as the owner of the service; only the operational responsibility is given to the contracting micro-enterprises. Informal waste collection activities were often haphazardly carried out by individuals and groups on their own initiative with no adequate monitoring by the municipality. Government officials adopted the 'de facto' partnership arrangement with microenterprises. Therefore, the city government saw the incorporation of informality (Fransen et al., 2010) as a desirable intervention in solid waste collection. Three types of informal solid waste collectors were important informal individuals, informal groups and informal organized groups:

1. Informal individuals collect waste temporarily to complement their livelihood. This job helps them to meet their immediate needs. In many cases, their service is preferred by households. People involved in this category are predominantly migrants

2. Informal groups are governed by a common interest and background. The relations among members are managed more by other interests than solid waste collection. The groups usually consist of more than two people and they collect waste temporarily to complement their income. They do not use any equipment

3. Informal organized groups consisting of more than two people. They use the job both for business and as a livelihood strategy. They use equipment for their work and are client oriented. Their payment is on a monthly basis and often some sort of leadership exists.

Informal solid waste collection in Addis Ababa has a long history. Oral evidence suggests that it existed prior to municipal solid waste collection. The informal activity existed in various 
forms from social to commercial enterprises. Hundreds of such micro-enterprises were in operation in the city. They provided house-to-house waste collection service. The Ministry of Work and Urban Development launched a proposal in 2006 under its 'Urban Good Governance' program about the role that could be played by the public sector, the people themselves and the private sector in relation to service delivery (MWUD, 2006). Subsequently, the city of Addis Ababa wished to follow-up on this work through various means such as building a partnership among all the relevant actors (formal and informal) and a campaign under the motto 'clean and green Addis', and became convinced that the task of primary solid waste collection should be entrusted to micro-enterprises, although the way they organized themselves and the structure of their governance had not really been institutionalized in the period 2004-2008.

\section{Methodology}

All types of informal/formal micro-enterprises were in place in 2009 , when this study was conducted. This offered an opportunity to look at all arrangements and to get a good understanding of the process of formalization and micro-privatization in Addis Ababa's waste collection. Data came from secondary and primary sources, and data collection involved both quantitative and qualitative techniques. One hundred and sixty micro-enterprises were included in the survey, about $35 \%$ of the total number. Secondary methods of data collection consisted of review of research reports, government official records, project documents, operational manuals and reports of different kinds; monthly, biannual and annual publications of the aligned institutions are taken as sources. Ten sub-cities were selected as sample areas. Five Kebeles were selected from each sub-city. The selection of these areas took into account whether the settlements were planned or unplanned, population density and the income level of the inhabitants. Stratified random sampling was employed for the survey. Sampling was done to ensure all of the various types of micro-enterprises within a particular area were represented. Stratified sampling was used in order to get a representative sample from each Kebele with specific type of the enterprise. Then, from each Kebele, 2-5 micro-enterprises were selected randomly based on the number and type of micro-enterprises available to each Kebele.

Survey, interviews and focus group discussions were used for primary data collection preceded by a reconnaissance visit and observation. A survey questionnaire was set for service providers to obtain primary data from micro-enterprises. Fifteen focus group discussions were conducted with different stakeholders: officers from the local government, technicians at the local government level, truck drivers, heads/owners of private microenterprises, workers of private micro-enterprises, workers of cooperative micro-enterprises and household groups. Twentyeight key informant interviews were held with representatives of the public sector at different levels (at the city council level, the sub-city level and local officials) to obtain data on solid waste

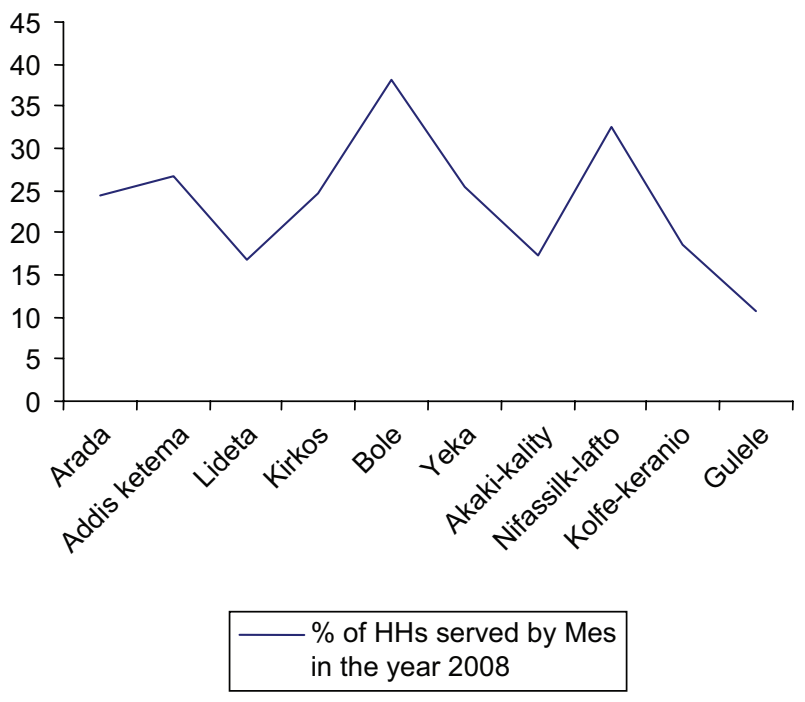

Figure 1. Households $(\mathrm{HH})$ served by micro-enterprises (MEs) in Addis Ababa.

collection and to get their views on solid waste collection through a public-private partnership arrangement (Bartone et al., 1991; Cointreau and Coad, 2000; Coad, 2005). The results are presented as follows and special attention will be paid to the increase in coverage, the type of clients served, the contractual models used, and the initiation and institutionalization of the formalization process.

\section{Results}

Micro-enterprises took over waste collection from the public sector and the households, and improved primary waste collection coverage from about 89 tonnes day ${ }^{-1}$ in 2002 to 121 tonnes day $^{-1}$ in 2008 (36\% improvement) (Figure 1). Interviews with city officials confirmed that, despite improvement in the collection service, micro-enterprises were unable to provide the level of service that was needed.

The level of demand or willingness to pay for primary solid waste collection services was low and difficult to ascertain. Some residents failed to realize that they have to pay for the service. Meanwhile, regarding enforcement regulation there was no municipal sanction for households who are not involved in the service scheme. Moreover, if the service provided by primary collectors is disrupted, the households have no place to appeal. In some cases, waste was dumped at the municipal skips by households themselves, although people lived in areas with limited access to municipal skips.

Private micro-enterprises focused on better-off clients and worked in more accessible areas. The ability to pay by households determines the engagement of private micro-enterprises in solid waste collection. Cooperative micro-enterprises were less successful than private micro-enterprises. During interviewing, local government bodies argued that private microenterprises have the problem of temptation to skim off the 


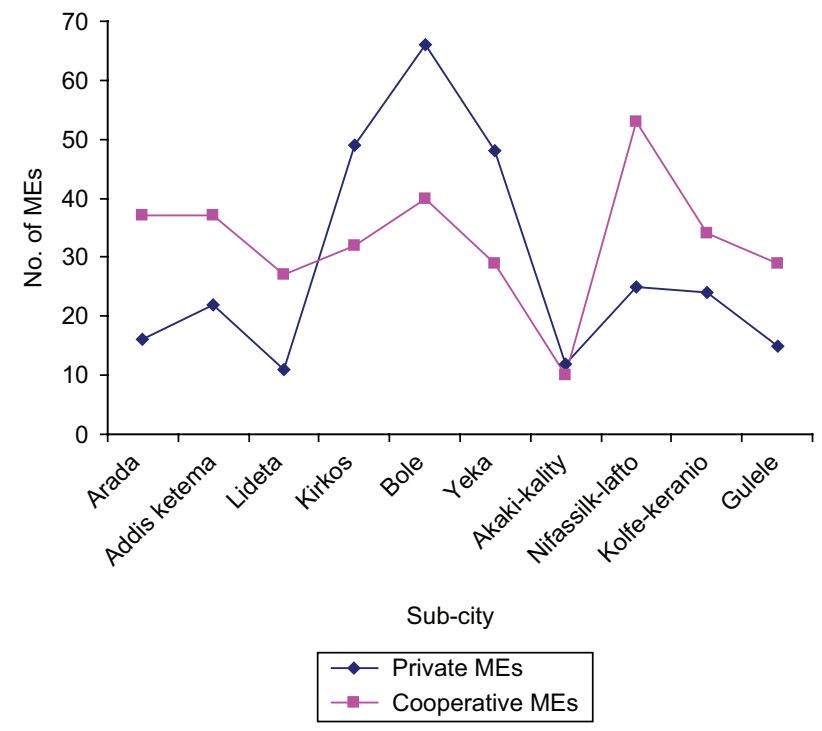

Figure 2. Distribution of micro-enterprise (ME) types to the sub-cities in 2008.

wealthiest households (who are most willing to pay and whose trash is likely to contain the most reusable and recyclable materials).

Figure 2 illustrates the distribution of private and cooperative micro-enterprises solid waste collectors in Addis Ababa engaged in primary solid waste collection in different sub-cities before June 2009. Private micro-enterprises are concentrating in the sub-cities of Bole, Yeka and Kirkos. Bole and Yeka are the subcities comprising better-off and more affluent inhabitants, while Kirkose is an old, central and densely populated area. The preexisting cooperative micro-enterprises were less successful than private micro-enterprises. One of the reasons they mentioned during the survey was that they were infringed and work in poor and infrastructurally less developed areas that are abandoned by the private micro-enterprises. The potential business areas are already taken up by the private micro-enterprises.

\section{Contractual models used in solid waste collection in Addis Ababa}

The 'Urban Good Governance' package (MWUD, 2006) of Ethiopia issued a document aimed at facilitating the delivery of services to the inhabitants in a cost-effective and efficient manner. These 'new public management' principles emphasize the importance of following different approaches to make service delivery and revenue collection efficient and effective (Van Dijk, 2006). In this regard, putting in place a service delivery plan and a system enforced by contracts with goals to utilize the private sector's skill and capacity is one of the major achievements of this process. 'Service users should pay' was another principle that was adhered to. A sustainable solution to waste problems in the larger cities in low- and middle-income countries requires a self-financing system in which all the real costs incurred are recovered through contributions from the beneficiaries (Harper, 2000). It is only when the 'social need' overtly transforms itself

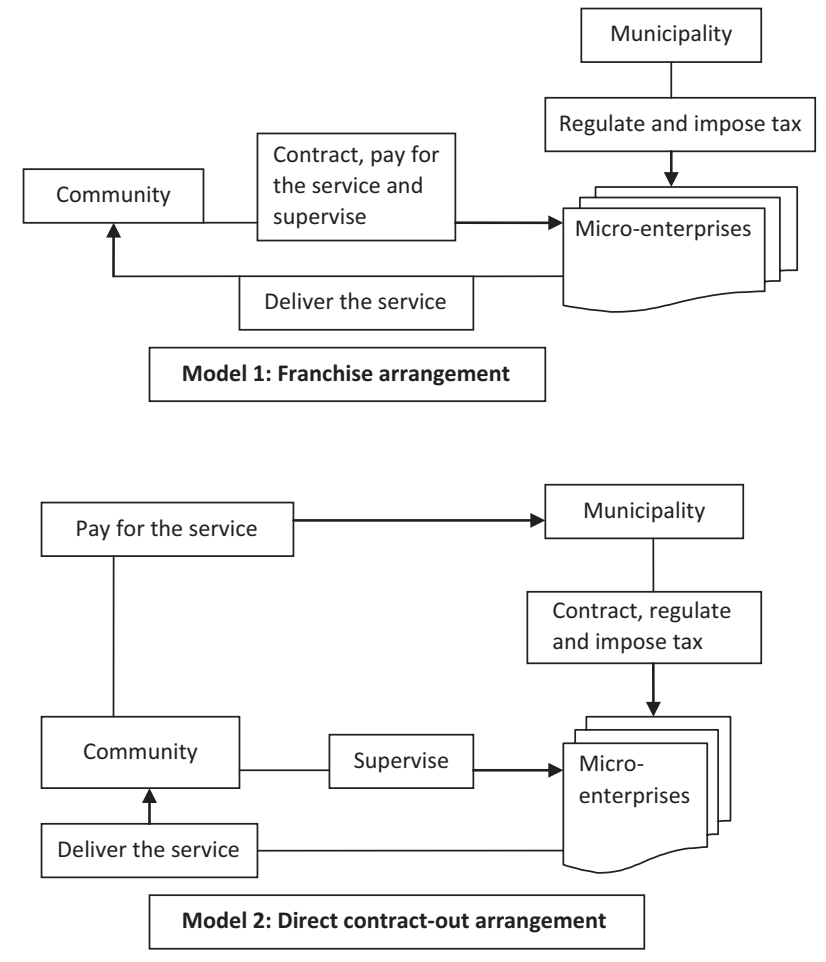

Figure 3. Contract models for involving micro-enterprises in Addis Ababa: solid waste collection ladapted from IPES, 1995).

as 'economic need' that private solid waste collection can become a reality (Coad, 2005; Cointreau and Coad, 2000).

Interviews with local officials revealed that before 2004 the micro-privatization of solid waste collection service provision was at its pilot stage. The system was more of the open competition type, but as time progressed the relationship with the government was predominantly the franchise formula with some elements of open competition. The private collection agents received support from the city, though the arrangements were not clearly defined, meaning that there was little direct interaction between the collection teams and the municipality.

After the arrival of the provisional city government in the year 2004, waste collection has gradually attracted more attention from officials (Zelalem, 2006). Later, when commercial private micro-enterprises were introduced in the city, the relationships between municipal authorities and micro-enterprises changed. Two types of contractual arrangements were introduced: franchising (in the period 2005-2009) and contract-out arrangements (after 2009) (Figure 3).

\section{Contract relation under franchise arrangement (2005-2008)}

Focus group discussion with owners of private micro-enterprises revealed that micro-enterprises were collecting waste from households to municipal skips (primary collection), while the city government was responsible for collecting waste from each of the intermediate neighborhood collection bins (secondary collection and transporting). Micro-enterprises collected the user 
charges from each household and other establishments that received services. Attempts were made to introduce tendering, but not on a real competitive basis.

Moreover, under the franchise arrangement some microenterprises started to partially sub-contract their working areas to individuals or groups who acted as labor providers. The sub-contractor would provide workers that would accomplish the task, as per the agreement made between the owner and the sub-contractor. There was also an arrangement that contract workers are employed by the micro-enterprises as casual labor. As one micro-entrepreneur said during focus group discussion it was not uncommon for some private commercial micro-enterprises to sign a contract for 3 years under a franchise arrangement. Micro-enterprises used to be contacted by the Kebele to renew their contract agreement when the contract period was completed. There were 288 private and 328 cooperative micro-enterprises by the year 2008. At the end of 2009, all these private companies were forced to change into cooperatives under a contract-out arrangement.

\section{Contract relation under a contract-out arrangement (after 2009)}

Contracting-out became the new mode of solid waste collection contract arrangement after 2009 (Domberger and Hall, 1996). Unlike franchising and open competition, where private agents collect fees directly from users, in a contracting-out arrangement the local governments pay the contractors according to the volume $\left(\mathrm{m}^{3}\right)$ of solid waste collected and hauled to the municipal skip, that is they contract-out solid waste collection to microenterprises to get them to collect waste from households and transfer it to the municipal skips at the designated place while keeping up the cleanness of their respective working zone.

The micro-privatization process of the service is based on the principle of public ownership and private operation. It is a condition where the public sector remains responsible for direct and indirect provision, but contracts out the service delivery to the private sector (Grimshaw and Willmott, 2002). The local government remains the owner of the service; only the operational responsibility is given to the contracting micro-enterprises. It was observed during the field study that the day-to-day administration of the solid waste collection service was handled by the Kebele's Integrated Solid Waste Management case team. The case team liaises closely with the micro-enterprises, the city authority and the community. The city authority's, Sanitation, Beautification and Park Development Agency (SBPDA), remains responsible for planning, providing guidelines and setting standards. The cooperative micro-enterprises play an important role in solid waste collection. When the city authorities introduced the contract-out system in 2009, they subsequently introduced four reforms:

- shift from a franchise to a contract-out arrangement;

- all micro-enterprises were obliged to change into cooperatives;

- all households in the city should be serviced and they are required to pay for the service;
- waste buying from micro-enterprises happens on a volume basis rather than providing a contract to do the job.

The micro-enterprises are obliged by the contract to collect waste only from households and their surroundings. The contract also stipulates that the contracting enterprises should abide by the regulation for service provision, such as obtaining the required necessary equipment and respecting standards of hygiene and workers safety. It has been observed during the field work that the contract was awarded to cooperative micro-enterprises without competitive bidding procedures. This violates the foundation of market-based competition among micro-enterprises and the government's expectations of cost-saving and quality improvement (Bel and Warner, 2008). The cooperatives were also reorganized and forced to work only within the locality they were assigned to. Micro-enterprises obtained a licence from the local government for the area in which they are working. They cannot open any branches in other locations or extend their business to other locations. The guidelines have banned their right to freely move and open branches in the other parts of the city.

Interviews with local officials revealed that the absence of a well-defined service area appeared to be one of the controversial issues and remained a source of conflict among different actors engaged in solid waste collection. Micro-enterprise garbage collectors did not have fixed collection routes, and there was open competition in certain areas. This resulted in inefficiencies, as up to three (or more) different collectors may work in the same street at the same time. This situation has led to selectively contracting with households that can afford relatively high service charges. It also limited inspection and monitoring of the performance of solid waste collection as there was no single enterprise to be held accountable. In addition, this condition involved extra expenses, as each enterprise had to deploy their employees to the sparsely and haphazardly located clients to collect service charges.

This negative experience led the SBPDA to prepare a directive on 'the delineation of service areas and service provision'. The SBPDA initiated a program to allocate zones to microenterprises and to give them a permit to operate, to prevent reckless dumping and to enhance accountability within their respective jurisdiction.

Given these reforms, local governments promised to assign between 650 and 1050 households to each micro-enterprise, and every enterprise works in its own jurisdiction only. The assumption by local governments was that zoning can force micro-enterprises to render account and they were expected to improve sanitation both at the neighborhood and the city level. Moreover, every household is required to pay for the solid waste collection service.

During focus group discussions micro-enterprises argued that during the introduction of zoning there were issues overlooked by the local government, such as wealth of the households, distance to a transfer station, access to alternative illegal dumping sites and the capacity of micro-enterprises. Different enterprises have different capacities, which determines how much microenterprises earn. 
Table 1. Who initiated micro-enterprises to solid waste collection task?

\begin{tabular}{lccc}
\hline & Frequency & Valid percent & Cumulative percent \\
\hline Kebele & 58 & 37.7 & 37.7 \\
Self & 35 & 22.7 & 60.4 \\
Private & 59 & 38.3 & 98.7 \\
Community & 2 & 1.3 & 100.0 \\
Total & 154 & 100.0 & \\
\hline
\end{tabular}

Some micro-enterprises had a problem with zoning as it was not done fairly by the Kebele. Owing to the new zoning rearrangement micro-enterprises lost long-term clients and they were forced to work with new ones. In some cases, those newly reorganized micro-enterprises are unable to manage the number of households they have been given because they do not have enough equipment, while others are complaining that the number of members in some cooperative micro-enterprises is too high and not in line with the size of the working zone allocated to them. Finally some enterprises do not get their monthly payment on time.

Under the contract-out system micro-enterprises do not sell the cleaning service, but they are selling the waste. Hence, microenterprises started to collect waste not only from the households but also from at every corner of the city. Moreover, it is observed that introduction of waste-buying by local governments suddenly increased the volume of waste handled at secondary points. Subsequently, the capacity within the public sector lacked the ability to cope with the new way of doing business. Eventually, this approach not only inflated the amount of waste that could go to the landfill, but also had an effect on recycling and composting, that is much of the waste that had been used as compost (as $>60 \%$ of the city waste is organic) was now being transported to the dumping site.

A key component of a local government's authority is to raise sufficient revenues to cover the payment for the volume of waste collected by micro-enterprises, and to supervise and monitor the cleanliness of the areas in question. It is observed that sometimes there was disagreement between the public officials (who judge the volume of waste) and the micro-enterprises. The officials complained that the waste is full of grass, which makes up the volume. However, there was no category of waste specified by the concerned body in the buying process. Also, there was no proper arrangement to measure the volume of waste. Hence, this is subjective. The equipment varies, and the nature and type of waste had not been taken into account when the system was developed. Micro-enterprises have accused local governments of poor and non-standardized measuring of the waste volume. In addition, even some households started complaining about giving waste freely to micro-enterprises as they heard microenterprises sell the waste to the local government.

Regarding the contract period, cooperative micro-enterprises signed only for a few months to test whether the pilot work was feasible or not, arguing that as a new group it was difficult to sign a long-term contract with the local government owing to the difficulty of predicting what will happen regarding the interest of the workers and the financial position of the enterprise. More than $90 \%$ of the micro-enterprises have a contract of $<6$ months. Moreover, local governments are not sure whether the fees collected from the community are sufficient to buy all the waste generated in the city. This makes local governments reluctant to follow the contract arrangement system very strictly.

Furthermore, as the contract system was totally tuned by the city government to cooperatives, some are pessimistic about the feasibility of this new arrangement, arguing that the system allows only for survival (livelihood) of members of cooperatives. In some cases, many people need to share the revenue, while the contract limits the possibility of expanding their business. Individual efforts are also disregarded, despite a lot of differences among members according to age, literacy rate, awareness level, and physical and mental strength. Given the above situation the workers argued that it was hard to sign a long-term contract.

The workers of cooperative micro-enterprises mentioned during the focus group discussion a number of problems associated with the newly developed contract arrangement:

- the contract forms were not uniform;

- the contracts were unilateral and press the contractor to perform

- the contract periods varied from Kebele to Kebele, even from enterprise to enterprise within the same Kebele.

During the interviews with officials they argued that the contractout arrangement did not deal with the problem of temptation by micro-enterprises to skim off the wealthiest households, which are the most willing to pay and their trash is likely to contain the most reusable materials. This leaves the poorest households with no collection system.

\section{Initiation and the role of the public sector}

To understand the challenges in the formalization process of solid waste collection micro-enterprises in Addis Ababa, the interventions made by public sector were considered from the point of view of initiation and institutionalization. Table 1 shows the survey results of how and by whom solid waste collecting microenterprises are initiated in Addis Ababa city, as responded to by the micro-entrepreneurs. As well as the approximately $38 \%$ reorganized existing informal waste collecting enterprises, which are now in the formal sector, approximately $23 \%$ replied that they decided themselves to organize a group of unemployed (or underemployed) young people and women from the community to collect solid waste from participating households and to transport it to a transfer station located centrally in each neighborhood. Finally, about $38 \%$ of the respondents said that they are involved in the work as they have been employees of private microenterprises. The micro-enterprises are the groups who joined the 


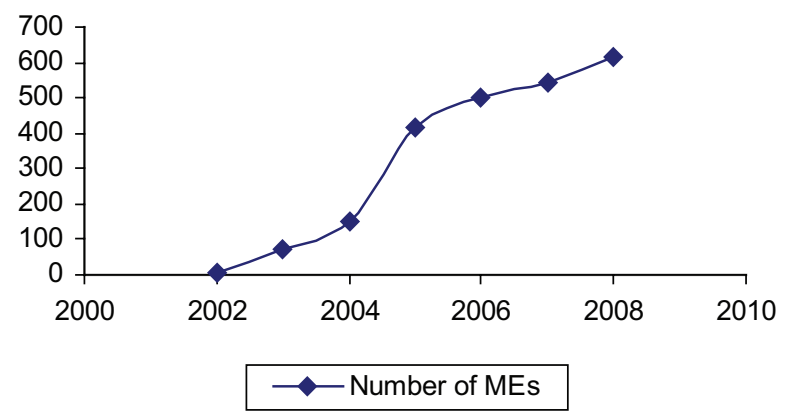

Figure 4. Involvement of micro-enterprises (ME) in solid waste collection services.

solid waste collection after becoming aware of the profitability of the activity.

Other developments also led the city government's SBPDA to reorient its service provision scheme. According to interviews with officials from SBPDA the process of formalization of solid waste collection micro-enterprises was stimulated by the growing concern of the city administration that it would not be possible to efficiently handle solid itself. Various internal and external factors (unemployment, increasing service demand, cost reduction strategy of the city and donor perspectives) have compelled the city authorities to change their policies concerning informal refuse collection, from neglect or repression, to tolerance or active support. This paved the way for the gradual withdrawal of the city government from the primary collection by appointing the micro-enterprises (Figure 4).

\section{The households' and workers' points of view}

Focus group discussions with households brought out that, in due course, micro-enterprises active in solid waste collection in Addis Ababa have received recognition from the community. Community leaders suggested that micro-enterprises were providing more effective and responsive services than previously provided by the public sector. Interviews with owners of private micro-enterprises revealed that households and other users appreciate the service (Kassim and Ali, 2006). In-depth interviews with owners of micro-enterprises revealed that the relations between micro-enterprises before 2004, when the informal scheme was dominant, took the form of conflicts, competition and collaboration. There was an opportunity for all kinds of micro-enterprise to work freely and exchange experiences. Gradually, in the period 2005-2008, when the private microenterprise scheme became dominant, conflicts developed as private micro-enterprises created a competitive environment through price reductions, better quality services and improvement of the worker's discipline.

Focus group discussions with workers of micro-enterprises revealed that there were two major groups of workers. The first group involves newcomers to the city. Some still have their own farm in a rural area and they are casual workers. They work for a short period of time and leave when they see other opportunities. The other group involves local people. The attitude of these workers depends on whether they work for a cooperative or a private micro-enterprise. Those who are organized as cooperatives are reluctant to do a good job as they get minimum rewards. Workers from private micro-enterprises claim that owners of private microenterprises swindle money that belongs to the workers.

The majority of the workers in the cooperative microenterprises are women and because there is no adequate material support they are sometimes forced to use their back to transport the waste from the households to the transfer stations. Moreover, during the field work it was observed that facilities have deteriorated and working conditions worsened as there is poor maintenance and no replacement of equipment under the cooperative arrangement.

Moreover, focus group discussions with owners of private commercial enterprises revealed only a minimum of collaboration between the public sector and micro-enterprises. Poor coordination between different levels of government was often mentioned by the micro-enterprises, which resulted in a poor performance of the waste collection micro-privatization process. Micro-enterprises had limited relations with the city administration bureaus and reasonably fair relations with their respective Kebeles. They have a quasi-official linkage with the City Sanitation, Beautification and Park Development Agency. Moreover, decisions are less transparent, even among different levels of government. What they are doing is in conflict with each other most of the time. Interviews with local officials revealed that part of this non-transparency among public sector offices arose owing to the fact that there were different interests within the public sector, implying different motives for government intervention. Consequently, this led to conflicts of interest between different parts of government. Local governments, despite being overwhelmed by various strategies coming from the top, were unable to successfully accomplish these tasks. In the meantime, as they were responsible for local issues, such as cleaning up of their vicinity, they could barely address the interests of city officials and the community as well.

\section{Institutionalization: No orderly authorization process}

At the beginning, authorization of micro-enterprises in Addis Ababa took place through various agencies with different modalities. Secondary sources from city government offices confirmed that, initially, the authority to promote formalization of microenterprises was given to the Trade and Industry Bureau and to the Micro- and Small Scale Enterprise Development Agency (MSSEDA). The SBPDA followed up the work technically. Focus group discussions with various workers revealed that micro-enterprises secure their licences from different sources. Licensing procedures were based on the type of micro-enterprise. Private commercial micro-enterprises got their licence from the sub-city's Trade and Industry Bureau and were expected to pay 
tax to the city government. Cooperatives micro-enterprises were getting their licences from the MSSEDA in the Kebele with the approval of the cooperative office, and they were tax-exempt.

Other enterprises obtained their licences from the city's Health Bureau. Some received their licence from the Trade and Industry Bureau, a work permit from the sub-city and in agreement with the Kebele. In some cases, the community provides authority to micro-enterprises to work in their neighborhood. Some workers are migrants or street people with no official residency and lack an identification card, which does not allow them to work in public offices. In such cases, the community provides them with support and negotiated with the Kebele.

Some micro-enterprises have a written agreement with the Kebele, given by the waste management team. Some obtain temporary work permits from local governments, or they had only an oral agreement with the Kebele. Still others use training certificates that have been given by the government and NGOs as a licence, and consider themselves authorized to do the job. Until 2009, all private commercial micro-enterprises, cooperative micro-enterprises and informal groups were working side-byside in the solid waste collection system, receiving different types of licence from different sources.

Interviews with local government officials revealed that although primary solid waste collection was handed over to micro-enterprises, the institutional arrangement was public ownership and private operation. As the ownership of the service belonged to the public sector, the public sector remained responsible for indirect provision. Given these institutional arrangements, the legitimacy of micro-enterprises is challenged in many ways. Focus group discussions with owners and workers revealed that, initially, the government tried to force private commercial enterprises to be organized under the auspice of MSSEDA, rather than assisting them as independent entities. This is against the will of most micro-enterprises, who prefer to operate as private firms. Moreover, the official capital requirements are a barrier to enterprises becoming formal. As stated in the guidelines for micro-enterprises engaged in solid waste collection and transportation, they are expected to have the necessary equipment (AACG, 2004). Registration for tax purposes is not a viable option for some informants, as the sector appears to them as unstable. Thus, the cost of registration coupled with the perceived irregular and erratic nature of the business discouraged them to become legitimate. Studies have estimated that full compliance with all regulations could mean closure of business. In Latin America, the cost of remaining legal varied between 17 and $70 \%$ of annual profits of the unit. In Bujumbura (Burundi) it was estimated that the revenue of micro-enterprises would be reduced by $48 \%$ if all regulations are strictly enforced (Nas and Jaffe, 2004).

The institutionalization of the micro-enterprises was not confined to the promotion of efficiency of solid waste collection. Rather, its focus was on boosting employment. In this regard, the government has a city-wide plan to deploy about 10,000 unemployed people in the solid waste collection sector. Accordingly, each Kebele has its own targeted quota and each Kebele official is held accountable for the number of people it organizes.
Micro-enterprises were asked about the level of agreement they have on 'the public sector's role as enabler'. Thirty percent of the surveyed enterprises agree that public sector could be a facilitator, while 35\% disagree. Twenty-eight percent of them are neutral ( $7 \%$ no answer). Micro-enterprises stated the reasons behind the poor facilitation role of the public sector: they got no response for their queries, appeal is not heard and no fair response is given to micro-enterprises. Moreover, rules and regulations are not respected, and the situation is unpredictable. An upcoming new regulation does not address the problems of microenterprises and is too administration-centered. Micro-enterprises and the public sector do not trust each other. This makes solid waste collection business unpredictable, which eventually makes the business unattractive. Micro-enterprises were asked about their freedom of decision. The survey showed that $22 \%$ considered that they do not have any freedom to decide on their matters. Thirty-one percent said they have little freedom, while 29\% said they have some freedom to decide ( $12 \%$ no answer). Also, regulation is changing without the consent and willingness of the partners in question, as decisions are made unilaterally.

\section{Discussion}

Three patterns evolved as the result of the government intervention to integrate solid waste collection micro-enterprises in Addis Ababa. The first pattern was that all the pre-existing informal actors and emerging private commercial and cooperative microenterprises co-existed, although with conflicts in a hostile environment. Second, it has been noted that there was a trend among informal solid waste collectors and cooperatives to move out to the marginalized areas. The third pattern to emerge was an effort by the government to gradually replace the private commercial businesses by cooperative micro-enterprises. The development of these patterns can be explained by the interplay of the preexisting informal solid waste collecting actors, the evolving private micro-enterprises and the initiative of local administration officials to institutionalize the cooperative micro-enterprises.

The potential of private commercial micro-enterprises seemed to have been grasped better, at least until 2008, in Addis Ababa. Entrepreneurs were free to arrange their own mix of labor input and technology which resulted in a certain diversity of approaches. It was well attuned to specific local circumstances. Monitoring and control mechanisms, and proper contract arrangement existed. However, the city government - preoccupied with concerns of public health and city beautification-wanted to answer these shortcomings in a technocratic manner. Contrary to the widely admitted need for competition to make private sector participation work, the city granted cooperative rights to microenterprises. This intervention, despite possible loss in service effectiveness, made business principles lose ground. This goes against the logic of market-based competition among microenterprises and the government expectation of cost-saving and quality improvement.

It was hard for cooperative micro-enterprises to continue the work as they lacked experience, were deprived of sufficient 
equipment and facilities, and had a poorly trained work force. Moreover, the partnership strategy in the contract arrangement and fee payment procedure did not sufficiently address the interests of the communities, which received differential treatment (and cross-subsidies) instead of a uniform approach. Zonal restriction resulted in fewer opportunities for micro-enterprises to compete and improve their service, as well as to expand their business.

\section{Conclusions}

Involving micro-enterprises as service providers must be tailored to specific local circumstances. The dynamics of solid waste collection reform in Addis Ababa are predominantly dictated by the relation between the local administration, communities and micro-enterprises. The question was how new opportunities created by formalization were taken up by communities and microenterprises, and how the authorities in the framework of micro-privatization used them. Special attention was paid to the increase in coverage and waste collected achieved.

Micro-enterprises in Addis Ababa city waste collection contribute tremendously by exploring opportunities that are appropriate to the milieu of the public sector and the community at large. Waste collection micro-enterprises in Addis Ababa exist because of public demand for the service, poverty and high unemployment. None of these factors is likely to disappear in the foreseeable future. Although policies at higher levels of government definitely produced an overall climate conducive to the rise of micro-privatization, the fate of the micro-enterprises was largely determined by the reforms undertaken at local government level.

The initiation and institutionalization of the formalization process was not without problems. The public sector overstressed the autonomy of micro-enterprises. The rapid changes in policies made waste-collecting micro-enterprises lose confidence in the government and more dependent on the public sector. It meant more costs as micro-enterprises had to adapt to the new arrangements. For example, Kokeb enterprise, in the sub-city of Nifas-silk lafto, started its business in 2001 as a private enterprise and in 2004 it was forced by local government to change to a cooperative. In 2005 it got the freedom to work again as a private micro-enterprise, and in 2009, for the second time, it was forced to change into a cooperative.

Strictly speaking, there is no clear strategy set for these microenterprises at that level. This prevents the full economic benefits being reaped from the market. Micro-enterprises working in solid waste collection in Addis Ababa felt the unpredictability of the city authority as a business partner owing to frequently changing policies and unbalanced regulations, while the latter accused the microenterprises of violation of health and environmental standards. The study shows the continued power of the state and its agents in shaping the developments in this domain. The policy at the national level recognized the need to develop micro-enterprises, but it was not clear what precise role the micro-enterprises are to play in solid waste management.

\section{Declaration of conflicting interests}

The authors do not have any potential conflicts of interest to declare.

\section{Funding}

The research was part of a $\mathrm{PhD}$ project at Erasmus university Rotterdam financed through a World Bank loan to Ethiopia.

\section{References}

AACG (Addis Ababa City Government) (ed.) (2004) Waste Management Collection and Disposal Regulations of the Addis Ababa City Government. Addis Ababa: Berhanena Selam Printing.

Bartone CR, Leite L, Triche T and Schertenleib R (1991) Private sector participation in municipal solid waste service: experiences in Latin America. Waste Management \& Research 9: 495-509.

Bel G and Warner M (2008) Does privatization of solid waste and water services reduce costs? A review of empirical studies. Resources, Conservation and Recycling 52: 1337-1348.

Coad A (ed.) (2005) Private Sector Involvement in Solid Waste Management: Avoiding Problems and Building on Successes. Eschborn: GIZ.

Cointreau L and Coad A (2000) Guidance Pack: "Private Sector Participation in Municipal Solid Waste Management”. St. Gallen: Swiss Centre for Development Cooperation.

Domberger S and Hall C (1996) Contracting for public services: A review of Antipodean Experience. Public Administration 74: 129-147.

Fransen J, van Dijk MP and Kassahun S (eds) (2010) Formalization and Informalization Processes in Urban Ethiopia: Incorporating Informality. Maastricht: Shaker, pp. 219.

Grimshaw V and Willmott H (2002) Going privately: partnerships and outsourcing in UK public service. Public Administration 80: $475-502$.

Harper M (2000) Public Services Through Private enterprise: Microprivatisation for Improved Delivery. London: IT.

IPES (Industrial \& Petroleum Environmental Services) (ed.) (1995) Cost Effective Solutions to Today's Environmental Concerns. Hallsville: IPES.

Kassim SM and Ali M (2006) Solid waste collection by the private sector: Households' perspective - Findings from a study in Dar es Salaam city, Tanzania. Habitat International 30: 769-780.

Kuma T (2004) Dry Waste Management in Addis Ababa City. Addis Ababa: Ethiopian Development Research Institute.

MWUD (Ministry of Work and Urban Development) (ed.) (2006) Urban Good Governance. Addis Ababa: MWUD.

Nas PS and Jaffe R (2004) Informal Waste Management: Shifting the Focus from Problem to Potential. Leiden: CNWS Research School, Leiden University.

Oduro-Kwarteng S and Van Dijk MP (2013) The effect of increased private sector involvement in solid waste collection in five cities in Ghana. In: Waste management \& research 31(10): 810-93.

Olugbenga A (2006) New approaches to solid waste management in Lagos. In: Solid waste, health \& Millennium Development Goals, A CWG-WASH workshop in Kolkata, Kolkata, India, 26-29 March 2006.

Pan African News Agency (ed.) (2004) Privatization in waste collection in Addis Ababa. Pan African News Agency, 22 February 2004.

Van Dijk MP (2006) Managing Cities in Developing Countries. Cheltenham: Edwar Elgar.

Van Dijk MP (2010) Incorporating Informality: 35 years of research and policies on the urban informal sector. In: Fransen J, et al. (eds) Maastricht: Shaker, pp. 1-15.

Velis CA, Wilson DC, Rocca O, Smith SR, Mavropoulos A and Cheeseman CR (2012) An analytical framework and tool for integrating the informal recycling sector in waste and resource management systems in developing countries. Waste Management \& Research 30 (Suppl.): 43-66.

Zelalem FC (2006) Controlling the Informal Sector: Solid Waste Collection and the Addis Ababa City Administration. 2003-2005 Masters' thesis, Geography Department, NTNU, Trondheim, pp. 120. 